\title{
TELOMERE SHORTENING IN PERIPHERAL BLOOD CELLS WAS RELATED WITH AGING BUT NOT WITH WHITE BLOOD CELL COUNT
}

\author{
Hiroe Satoh, Keiko Hiyama,* Masahiro Takeda, Yukikazu AwayA, \\ Kenichiro Watanabe, Yoshinao Ihara, Hiroyuki Maeda, \\ Shinichi ISHIOKA, and Michio YAMAKIDO
}

\begin{abstract}
Second Department of Internal Medicine, Hiroshima University School of Medicine, 1-2-3 Kasumi, Minami-ku, Hiroshima 734, Japan
\end{abstract}

\begin{abstract}
Summary Telomeres in somatic cells are progressively shortened with aging. We investigated the relationship between the telomere length and other factors which may affect the frequency of cell divisions, in peripheral blood cells. Shortening of telomeric repeats was correlated with aging $(\mathrm{p}<0.0001)$, but not with white blood cell count, neutrophil count, and smoking habit. Not only the number of cell divisions, but also some other factors, such as upregulation level of telomerase activity concomitant with the cell division in hematopoietic progenitor cells, might affect the length of telomeric repeats in blood cells.
\end{abstract}

Key Words telomere, blood cell, aging, cell division, white blood cell count

Both ends of human chromosomes consist of repeated DNA sequences, called telomeres. It has been widely accepted that this repeated (TTAGGG) n $_{\mathrm{n}}$ sequences are progressively shortened with each cell division in somatic cells, causing cellular senescence, and that the shortened telomeres can be extended by a ribonucleoprotein, telomerase, in germline cells and immortal cancer cells (Shay, 1995). Thus, the telomere shortening in peripheral blood cells with aging has been observed, whereas there was a wide variance among individuals (Hastie et al., 1990; Ohyashiki et al., 1994). Recently we found that hematopoietic progenitor cells as well as lymphocytes have telomerase activity (Hiyama et al., 1995a), using Telomeric Repeat Amplification Protocol (TRAP) assay (Kim et al., 1994), and the activity in peripheral blood mononuclear cells decreases with aging. It is now

Received June 24, 1996; Revised version accepted September 30, 1996.

* To whom correspondence should be addressed. 
believed that stem cells in renewal tissues, not only hematopoietic cells but also crypts of intestinal tract (Hiyama et al., 1996) and epidermis of the skin (Taylor et al., 1996), have telomerase activity which partially compensates for the telomere shortening to provide extended proliferative capacity. To find the factors that affect the rate of telomere shortening in blood cells, we measured the telomere length in a large number of individuals and analyzed the relationship between the telomere length and age, white blood cell count, and smoking habit.

\section{Materials and Methods}

Peripheral blood samples were obtained from a total of 352 Japanese individuals. Among them, 186 (134 males and 52 females) individuals ranging 25 to 67 years old are employees of a company and 166 (153 males and 13 females) individuals ranging 62 to 95 years old are former workers in a poison gas factory at Ookuno-jima island during World War II. Blood was drawn for seasonal health examination and the remaining portion was used for this study.

Genomic DNA was extracted from total blood cells using DNA Extractor WB $\mathrm{Kit}^{\mathrm{TM}}$ (Wako). Five micrograms of DNA was digested to completion with Hinfl, subjected to electrophoresis on $1 \%$ agarose gels, blotted onto nitrocellulose filters, and then hybridized to a $\left[\gamma^{-32} \mathrm{P}\right]$ ATP labeled (TTAGGG) $)_{4}$ probe at $50^{\circ} \mathrm{C}$ as previously described (Hiyama et al., 1995b). The filters were washed in $4 \times \mathrm{SSC}$ $\left(1 \times=0.15 \mathrm{M} \mathrm{NaCl}, 0.015 \mathrm{M}\right.$ sodium citrate) and $0.1 \% \mathrm{SDS}$ at $55^{\circ} \mathrm{C}$ four times and exposed to $\mathrm{X}$-ray film (Fig. 1). The mean length of telomeric repeats was estimated

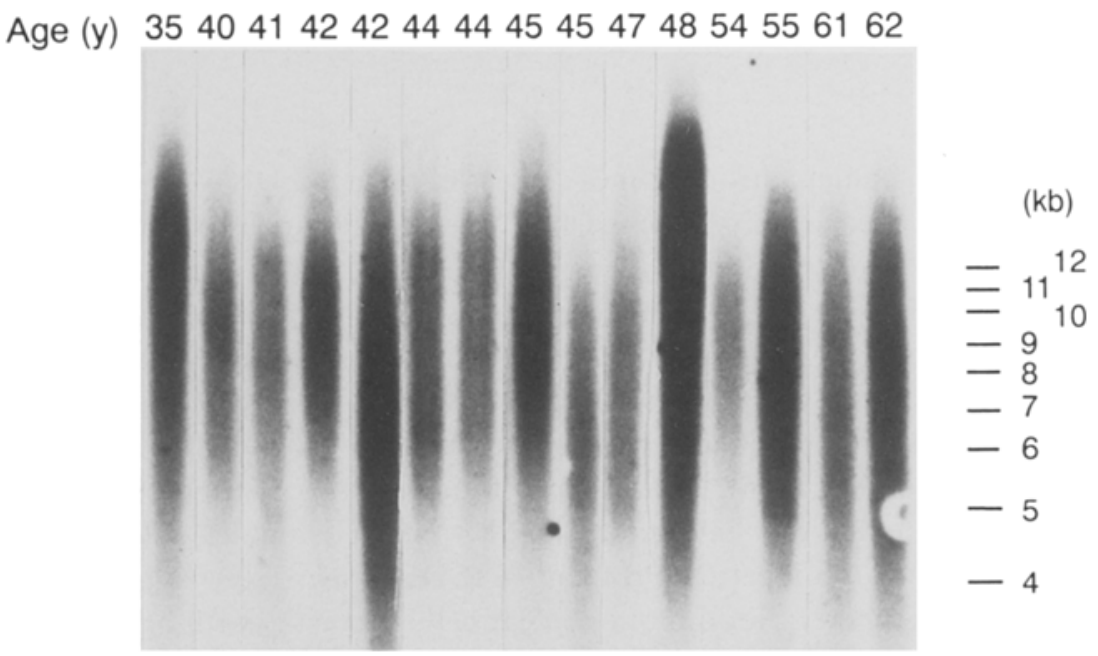

Fig. 1. Southern blot analysis of telomeric repeats in peripheral blood cells from representative 15 individuals. The mean length of telomeric repeats was estimated as the peak of the smear signals. 



Fig. 2. Relationships between the mean length of telomeric repeats in peripheral blood cells and other factors: age $(A, n=352)$, white blood cell counts $(B, n=165)$, neutrophil counts $(C, n=165)$, and smoking habit $(D, n=166)$. Shortening of telomeric repeats was correlated with aging $(p<0.0001)$, but not with white blood cell counts, neutrophil counts, and smoking habit.

as the peak of the smear signals visually determined and confirmed by densitometer (ATTO) or BAS 2000 (Fuji).

The relationships between the mean length of telomeric repeats and the age, white blood cell counts, neutrophil counts, and smoking habit were compared.

\section{Results}

Although the mean length of telomeric repeats in peripheral blood cells varied over a wide range as previously reported, it shortened with age $(n=352$; $\mathrm{m}=-31 \mathrm{bp} /$ year; $\mathrm{r}=0.291 ; \mathrm{p}<0.0001$, Fig. $2 \mathrm{~A}$ ). When it was analyzed separately among the 186 employees and the 166 former workers in the poison gas factory, the telomere shortening with aging was also statistically significant in both $(\mathrm{n}=186$; $\mathrm{m}=-63 \mathrm{bp} /$ year; $\mathrm{r}=0.339 ; \mathrm{p}<0.0001$ and $\mathrm{n}=166 ; \mathrm{m}=-52 \mathrm{bp} /$ year; $\mathrm{r}=0.186 ; \mathrm{p}<$ 0.0001 , respectively). When the mean length of telomeric repeats in peripheral blood cells was compared with the number of white blood cells $(25 \leq \mathrm{y} \leq 67 ; \mathrm{n}=$ $165 ; r=0.060$, Fig. 2B) and with that of neutrophils $(25 \leq y \leq 67 ; n=165 ; r=0.080$, 
Fig. 2C) in 165 individuals among the 186 employees, no significant relationship was observed. When the mean length of telomeric repeats in peripheral blood cells was compared with the smoking habit, as a chronic stimulatory factor over 40 years, in the 166 former workers in the poison gas factory $(62 \leq y \leq 95)$, no significant relationship was observed (Fig. 2D). Before this analysis, we had confirmed that there was no significant difference with age between the smokers and the non-smokers ( $p=0.4838$, Mann-Whitney's U test).

\section{Discussion}

The present result with large Japanese population $(\mathrm{n}=352)$ that the mean length of telomeric repeats in peripheral blood cells is shortened by $31-63 \mathrm{bp} /$ year is compatible with the previous reports with relatively small population (33-42 bp/year) (Hastie et al., 1990; Ohyashiki et al., 1994).

Based on the assumption that the life span of neutrophils is similar among individuals, we speculated that the neutrophil count would reflect the frequency of stem cell division. However, no relationship was observed between the telomere length and neutrophil counts, nor was with white blood cell count. Moreover, although it is known that total white blood cell and neutrophil counts increase in smokers (Bridges and Rehm, 1987), no relationship was observed between the telomere length and smoking habit. Considering the fact that hematopoietic progenitor cells and lymphocytes have telomerase activity (Hiyama et al., 1995a), we concluded that not only the number of cell divisions the blood cells have gone through, but also some other factors, such as upregulation level of telomerase activity concomitant with the cell division of hematopoietic progenitor cells or lymphocytes, would affect the length of telomeric repeats in blood cells.

Acknowledgments We greatly thank Dr. Kimihiko Nakamura for his generous support in statistical analysis. This work was partly supported by research grants from the Ministry of Health and Welfare of Japan and the Ministry of Education, Science, Sports and Culture of Japan.

\section{REFERENCES}

Bridges RB, Rehm SR (1987): Chronic cigarette smoking and obstructive pulmonary disease: peripheral blood leukocytes, neutrophil elastase, myeloperoxidase activities, and serum antiprotease. In: Taylor JC, Mittman C (eds). Puimonary emphysema and proteolysis: 1986. Academic Press, Orlando, pp 393-398

Hastie ND, Dempster M, Dunlop MG, Thompson AM, Green DK, Allshire RC (1990): Telomere reduction in human colorectal carcinoma and with ageing. Nature 346: 866-868

Hiyama K, Hirai Y, Kyoizumi S, Akiyama M, Hiyama E, Piatyszek MA, Shay JW, Ishioka S, Yamakido M (1995a): Activation of telomerase in human lymphocytes and hematopoietic progenitor cells. J Immunol 155: 3711-3715

Hiyama K, Ishioka S, Shirotani Y, Inai K, Hiyama E, Murakami I, Isobe T, Inamizu T, Yamakido M (1995b): Alterations in telomeric repeat length in lung cancer are associated with loss of heterozygosity in $\mathrm{p} 53$ and $\mathrm{Rb}$. Oncogene 10: 937-944

Hiyama E, Hiyama K, Tatsumoto N, Kodama T, Shay JW, Yokoyama T (1996): Telomerase 
activity in human intestine. Int $\mathrm{J}$ Onc 9: 453-458

Kim NW, Piatyszek MA, Prowse KR, Harley CB, West MD, Ho PLC, Coviello GM, Wright WE, Weinrich SL, Shay JW (1994): Specific association of human telomerase activity with immortal cells and cancer. Science 266: 2011-2015

Ohyashiki JH, Ohyashiki K, Fujimura T, Kawakubo K, Shimamoto T, Iwabuchi A, Totama K (1994): Telomere shortening associated with disease evolution patterns in myelodysplastic syndromes. Cancer Res 54: 3557-3560

Shay JW (1995): Aging and cancer: are telomeres and telomerase the connection? Mol Med Today 1: $378-384$

Taylor RS, Ramirez RD, Ogoshi M, Chaffins M, Piatyszek MA, Shay JW (1996): Detection of telomerase activity in malignant and nonmalignant skin conditions. J Invest Dermatol 106: $759-765$

Vol. 41, No. 4, 1996 